\title{
UPAYA MENINGKATKAN KEMAMPUAN GURU MENYUSUN RENCANA PELAKSANAAN PEMBELAJARAN HARIAN (RPPH ) MELALUI TEHNIK LATIHAN DAN BIMBINGAN PADA GURU TK/PAUD GUGUS I KECAMATAN WOLOMEZE TAHUN PELAJARAN 2018/2019
}

\author{
Anastasia Weti \\ Pengawas TK/PAUD Kabupaten Ngada
}

\begin{abstract}
Tujuan penelitian tindakan sekolah ini adalah untuk meningkatkan kemampuan guru dalam menyusun Rencana pelaksanaan pembelajaran Harian melalui kegiatan latihan dan bimbingan pada guru TK/PAUD di Gugus I, Kecamatan Wolomeze, Kabupaten Ngada, TA 2018/2019. Jenis penelitian adalah penelitian tindakan sekolah. Prosedur penelitian ini terdiri atas tahapan perencanaan tindakan, pelaksanaan tindakan, observasi, dan refleksi, yang dilakukan dalam dua siklus. Tempat penelitian di TK/PAUD gugus I, Kecamatan Wolomeze. Subyek dalam penelitian ini adalah guru - guru di TK/PAUG gugus I Kecamatan Wolomeze yang berjumlah 6 orang. Metode pengumpulan data menggunakan metode wawancara, obeservasi dan dokumentasi. Analisis data yang digunakan adalah teknik analisis deskriptif komparatif. Data kuantitatif yang diperoleh dideskripsikan dalam bentuk kata-kata atau penjelasan. Selanjutnya dilakukan komparasi data untuk memastikan ada tidaknya peningkatan kinerja guru dalam pelaksanaan pembelajaran di Kelas. Dari rata-rata nilai dalam menyusun rencana pelaksanaan pembelajaran harian (RPPH) pada kondisi awal diperoleh $59 \%$ berada pada kategori kurang . Pada ahir Siklus I rata - rata nilai yang diperoleh $67,83 \%$ berada pada kategori cukup, di akhir siklus II diperoleh $84,67 \%$, berada pada kategori baik. Dari kondisi awal sampai dengan akhir siklus II nilai kemampuan guru dalam meyusun RPPH meningkat sebesar 25,67\%. Hal ini dapat disimpulkan bahwa dengan melaksanaka latihan dan bimbingan, maka dapat meningkatkan kemampuan guru dalam menyusun rencana pelaksanaan pembelajaran harian (RPPH) pada Guru TK/PAUD di Gugus I , Kecamatan Wolomeze, Kabupaten Ngada TA 2018/2019.
\end{abstract}

Kata kunci: Latihan dan Bimbingan, kemampuan guru, Rencana pelaksanaan pembelajaran Harian 


\section{PENDAHULUAN}

Peraturan pemerintah Nomor 19 Tahun 2005 tentang Standar Nasional Pendidikan dan tenaga kependidikan, dinyatakan bahwa pendidik harus memiliki kualifikasi akademik dan kompetensi sebagai agen pembelajaran,sehat jasamani dan rohani serta memiliki kemampuan untuk mewujudkan tujuan pendidikan nasional. Kualifikasi akademik yang dimaksud adalah tingkat pendidikan yang minimal yang harus dipenuhi oleh seorang pendidik dan dibuktikan dengan ijasah dan sertifikat keahlian yang relevan sesuai dengan ketentuan perundang-undangan yang berlaku.

Selain kualifikasi akademik, guru juga harus memiliki seperangkat kompetensi.

Kompetensi guru sebagai agen pembelajaran pada jenjang pendidikan anak usia dini meliputi 4 kompetensi yaitu sebagai berikut : 1 Kompetensi pedagogik, 2. Kompetensi kepribadian 3. Kompetensi profesional, 4. Kompetensi sosial yaitu

Pendidik PAUD harus memiliki kualifikasi akademik dan kompetensi yang memadai, mempunyai wawasan pengetahuan dan menunjukan kinerja dengan kualitas yang tinggi, memiliki bakat, minat, panggilan jiwa, dan memiliki komitmen untuk meningkatkan mutu pendidikan, keimanan, ketakwaan dan ahlak mulia serta sehat, jasmani dan rohani.

Untuk menjadi pendidik anak usia dini haruslah pendidik PAUD yang kaya. Istilah "kaya " dipopulerkan oleh Amir dan Erlin dalam sebuah bukunya yang terinspirasi dari sebuah buku yang berjudul Pumping Teacher. Pengertian "kaya " yang dimaksud dalam buku tersebut bukanlah kaya dalam arti materi uang , harta ) saja, melainkan kaya akan informasi sehingga lebih bijaksana dalam mendidik anak. Guru "kaya " tidak menganggap pekerjaan menjadi guru suatu pekerjaan panggilan ( banyak waktu liburnya ) dan hanya sebatas memperoleh " honor " secara rutin setiap bulan, tetapi guru kaya adalah guru yang mempunyai perhatian dan empati terhadap anak-anaknya,dan terus mengasah pemikirannya dan memperkaya seni mengajar, dengan menerapkan berbagai metode yang bervariasi sehingga menyenangkan siswanya.

Dari uraian tersebut di atas dapatlah disimpulkan bahwa menjadi 
guru PAUD haruslah guru yang mempunyai kualifikasi akademik dan kompetensi serta guru yang "kaya" akan informasi sehingga menjadi lebih bijaksana dalam mendidik anak, mempunyai hati yang lapang dalam mengadapi berbagai persoalan hidup, mempunyai perhatian dan empati terhadap anak, mengasah pemikirannya dan memperkaya seni mengajar dengan menerapkan berbagai metode. Dan untuk mencapai semua itu maka guru dituntut untuk merancang semua ide - ide tersebut yang dituangkan dalam suatu pesiapan yang disebut dengan istilah " Rencana Pelaksanaan Pembelajaran harian ( RPPH )." $\mathrm{RPPH}$ yang direncanakan guru harus didesain sedemikian rupa sehingga materi pembelajaran yang akan diajarkan dapat memotivasi anak sehingga anak merasa nyaman , aktif dan bersemangat dalam mengikuti proses pembelajaran di sekolah serta untuk membentuk sikap, pengetahuan dan keterampilan peserta didik yang lebih konsisten sejak awal sehingga diharapkan peserta didik mampu berkembang sumber daya manusia yang memiliki kompetensi sikap beragama,kreatif,inovatif,dan erdaya saing dalam lingkungan yang lebih luas.

Masalah penting yang sering dihadapi guru dalam kegiatan pembelajaran adalah menyiapkan Rencana Pelaksanaan Pembelajaran Harian ( RPPH ) yang tepat dalam rangka membantu siswa mencapai kompetensi. Hal ini disebabkan oleh kenyataan bahwa dalam kurikulum atau silabus, Rencana

Pelaksanaan Pembelajaran Harian hanya dituliskan secara garis besar dalam bentuk " materi acuan untuk mengajar “. Menjadi tugas guru untuk menjabarkan materi acuan untuk mengajar tersebut, sehingga menjadi bahan ajar yang lengkap

Penyusunan

rencana pembelajaran Harian merupakan suatu pembagian terpenting dalam melaksanakan proses belajar mengajar di kelas. Dikatakan penting , karena untuk guru, RPPH tersebut merupakan acuan atau skenario yang harus dilalui tahap demi tahap dalam memberikan materi kepada siswa Dalam pelaksanaan proses belajar mengajar, setiap guru wajib menjadi syarat mutlak untuk membuat RPPH , sebelum proses penampilan di dalam kelas. Dalam penyusunan 
$\mathrm{RPPH}$ ini , setiap guru harus berpedoman pada program Semester dan program Pelaksanaan Pembelajaran Mingguan serta kalender akademik/Kalender Tatap muka pada satu tahun pelajaran berlangsung .

Adapun keuntungan yang diperoleh dari pembuatan RPPH adalah sebagai berikut guru akan lebih percaya diri dalam menyampaikan materi pembelajaran kepada siswa, karena telah dipersiapkan sebelumnya, guru dapat menyampaikan materi pembelajaran dengan alur yang telah direncanakan, guru dapat menggunakan RPPH tersebut untuk mengatur durasi penyampaian materi pembelajaran .

Namun kenyataan yang ada di lapangan guru-guru yang mengajar di PAUD Kecamatan Wolomeze, terdiri dari 2 Orang sarjana Pendidikan Sekolah Dasar ( S1 PGSD ), dan 4 Orang tamatan SMA. Dengan demikian kemampuan mereka dalam merancang atau mendesain Rencana Pelaksanaan Pembelajaran Harian ( RPPH ) masih harus memerlukan bimbingan dan pelatihan. Selain yang dihadapi di lapangan yaitu di kecamatan Wolomeze masih banyak guru yang belum mampu menyusun Renaca Pelaksanaan Pembelajaran Harian sesuai dengan alokasi waktu yang ditetapkan dalam kalender tatap muka bahkan masih ada beberapa guru pada beberapa sekolah yang dalam satu semester hanya menyusun sekitar 4 - 5 RPPH saja. Guru belum mampu mendesain pembelajaran yang menarik minat siswa untuk mengikuti proses belajar mengajar yang dilaksanakan guru di kelas. Mereka lebih memilih mengikuti orang tuanya ke kebun atau ke sawah dari pada ke sekolah, karena kegiatan yang dirancang guru tidak bervariasi. Guru jarang menggunakan RPPH dalam proses belajar mengajar, guru belum mengerti tentang bagaimana cara yang tepat untuk membuat Rencana Pelaksaan pemberalaran Harian ( $\mathrm{RPPH}$ ), tingkat pendidikan yang diperoleh guru belum sesuai dengan yang diharapkan, kurangnya keterlibatan guru dalam mengikuti berbagai pelatihan dalam wadah kelompok kerja guru ( $\mathrm{KKG} \mathrm{),}$ kurangnya motovasi guru terhadap pendidikan anak usia dini, salah satu faktor utama adalah kesulitan guru dalam mendesain atau membuat Rencana Pelaksanaan Pembelajaran Harian ( RPPH ). 
Berangkat dari permasalah di atas, maka dianggap perlu untuk mencarikan solusi untuk meningkatkan kemampuan dalam membuat Rencana Pelaksanaan Pembelajaran Harian guru-guru PAUD di Kecamatan Wolomeze. Dalam rangka meningkatkan kemampuan guru tersebut, maka di lakukan pelatihan dan bimbingan bagi guru dalam menyusun rencana pelaksanaan pembelajaran harian dengan baik dan benar yang sesuai dengan tahap-tahap perkembangan anak usia dini. Bimbingan dan latihan merupakan salah satu cara untuk meningkatkan kemampuan guru . Menurut Mathis (2002), Pelatihan adalah proses dimana orang mencapai kemampuan tertentu untuk mencapai tujuan organisasi. Hakim (dalam Kurniawati 2009:74) menyatakan, "bahwa perencanaan program pembelajaran pada hakekatnya merupakan perencanaan program jangka pendek untuk memperkirakan suatu proyeksi tentang sesuatu yang akan dilakukan dalam kegiatan pembelajaran".

Menurut Prayitno \& Amti (2004) bimbingan adalah proses pemberi bantuan yang dilakukan oleh orang yang ahli kepada seseorang atau beberapa orang individu,baik anakanak remaja,maupun dewasa agar orang-orang yang dibimbing dapat mengembangkan kemampuan dirinya sendiri dan mandiri,dengan memanfaatkan kekuatan individu dan sarana yang ada dan dapat dikembangkan berdasarkan normanorma yang berlaku.

Diharapkan dengan mengadakan Latihan dan bimbingan tersebut dapat meningkatkan kemampuan guru dalam membuat atau menyusun Rencana Pelaksanaan Pembelajaran Harian alasannya bimbingan dan latihan memberikan kesempatan kepada guru untuk bekerja sendiri dan teman sejawat.

Berdasarkan uraian diatas maka tujuan dari penelitian ini adalah untuk mengetahui peningkatan kemampuan guru dalam meyusun rencana pelaksanaan pembelajaran dengan melakukan latihan dan bimbingan pada guru TK/PAUD Gusus I, Kecamatan Wolomeze, TA 2018/2019

\section{METODE PENELITIAN}

Penelitian tindakan sekolah ini dilaksanakan pada bulan bulan September-Nopember 2018, di TK/PAUD Gugus I Kecamatan Wolomeze . Subyek penelitian 
adalah guru - guru PAUD di Kecamatan Wolomeze

Penelitian ini dilaksanakan dalam 2 siklus dan masingmasing siklus terdiri dari 4 tahap yaitu : (1) tahap perencanaan program tindakan, (2) pelaksanaan program tindakan, (3) pengamatan program, (4) refleksi. Metode pengumpulan data adalah Wawancara menggunakan panduan wawancara, Observasi menggunakan lembar, Diskusi dilakukan dengan maksud untuk sharing pendapat antara peneliti dengan guru.

Instrumen penilaian yang digunakan adalah : Pedoman Wawancara untuk menggali pengetahun guru - guru tentang penyusunan $\mathrm{RPPH}$, Pedoman Observasi, Catatan, dan Dokumentasi

Analisis data yang digunakan adalah teknik analisis deskriptif komparatif. Data kualitatif yang diperoleh dideskripsikan dalam bentuk kata-kata atau penjelasan. Selanjutnya dilakukan komparasi data untuk memastikan ada tidaknya peningkatan kemampuan guru dalam menyusun perencanaan pembelajaran, peningkatan kemampuan guru dalam pelaksanaan. Sebagai tolok ukur keberhasilan pelaksanaan Siklus I dan Siklus II perlu diketahui indikator pencapaian hasil penelitian. Sebagai tolok ukur keberhasilan pelaksanaan penelitian tindakan kelas ini ditetapkan indikator kinerja yaitu persentase jumlah skor perolehan menyusun RPPH meningkat 25\%.

Tiap instrumen penilaian terdapat 5 kualifikasi penilaian yaitu 1, 2, 3, 4 dan 5 Setiap skor yang diperoleh kemudian dibagi dengan skor maksimal dan dikalikan dengan 100 atau

$$
\mathrm{N}=\frac{\text { skor yang diperoleh }}{\text { skor maksimal }} \times 100
$$

Adapun kriteria penilaian yaitu: Baik Sekali berada di skor 91 sampai 100, Baik berada pada skor 76 sampai 90, Cukup berada pada skor 61 sampai 75, Kurang berada pada skor 51 sampai 60 , sedangkan Kurang Sekali berada pada skor kurang dari 50.

\section{HASIL DAN PEMBAHASAN}

Penelitian Tindakan Sekolah ini dilaksanakan pada guru TK/PAUD di Gugus 1 Kecamatan Wolomeze, Kabupaten Ngada. Subiek yang diteliti adalah guru - guru TK/PAUD yang berjumlah 6 orang. Penilaian yang dilaksanakan disini adalah lebih di fokuskan pada penilaian 
dalam penyusunan Rencana

Pelaksanaan Pembelajaran Harian (RPPH). Kondsi awal yang ditemukan dilapangan sebelum peneliti yang dalam hal ini adalah pengawas TK/PAUD di kecamatan Wolomeze membuat tindakan dalam pelaksanaan penelitian dapat ditampilkan hasil penilaian pada tabel berikut ini.

Tabel 1 Kondisi Awal Penilaian $\mathrm{RPPH}$

\begin{tabular}{|c|c|c|c|}
\hline No & \multirow{2}{*}{$\begin{array}{c}\text { Nama } \\
\text { Guru }\end{array}$} & \multicolumn{2}{|c|}{$\begin{array}{c}\text { Penyusunan } \\
\text { RPPH }\end{array}$} \\
\cline { 3 - 4 } & & Nilai & Ket \\
\hline 1 & MFK & 60 & K \\
\hline 2 & MS & 50 & KS \\
\hline 3 & MFL & 60 & K \\
\hline 4 & BD & 60 & K \\
\hline 5 & LR & 62 & C \\
\hline 6 & NN & 62 & C \\
\hline & Jumlah & 354 & \\
\hline & $\begin{array}{c}\text { Rata- } \\
\text { rata }\end{array}$ & 59 & \\
\hline
\end{tabular}

Dari tabel di atas dapat diketahui rata - rata nilai dari hasil supervisi pengawas dalam pembuatan RPPH diperoleh 59\% berada pada kategori kurang. Dilihat dari penilaian individu nilai perolehan berkisar pada rentangan $50-62$. Dari data

diatas dapat diketahui ada 1 orang guru $16,67 \%$ memperoleh nilai 50 , berada pada kategori sangat kurang, 3 orang guru $50 \%$ memperoleh nilai 60 berada pada kategori kurang, dan 2 orang guru $33,33 \%$ memperoleh nilai 62 berada paga kategori cukup. Dari hasil yang diperoleh baik secara individu maupun setelah dirata - ratakan dapat disimpulkan bahwa kemampuan guru dalam menyusun $\mathrm{RPPH}$ masih sangat rendah. Kondisi ini perlu mendapat perhatian serius oleh pengawas maupun pihak sekolah. Pelaksanaan supervise yang dilakukan oleh pengawas selama ini adalah sebuah kegiatan rutin yang harus dilaksanakan sebagaimana sesuai dengan jadwal kegiatan pengawas. Dari segi kualifikasi guru juga ditemukan persoalan di lapangan dari ke 6 guru hanya 2 orang yang memiliki kualifikasi S1, Dari kondisi inilah yang menjadi salah satu penyebab atau masalah dalam kegiatan pembelajaran, dimana guru belum bisa membuat RPPH dengan baik dan benar. Para guru membuat RPPH sesuai dengan kemampuan mereka, yang menyebabkan dalam pelaksanaan pembelajaran mereka mengajar sesuai dengan apa yang bisa mereka lakukan. Kondisi inilah yang membuat peniliti dalam hal ini adalah sebagai pengawas berupaya untuk mencarikan solusi agar guru bisa memiliki pengetahuan dan bisa 
membuat RPPH yang baik dan benar. Untuk itu peneliti menggunakan model pelatihan dan bimbingan dalam membuat RPPH untuk guru. Adapun hasil pelatihan dan bimbingan dapat dideskripsikan pada pelaksanaan Siklus I dan II di bawah ini.

Tabel 2. Nilai Kemampuan

Penyusunan RPPH Siklus I dan Siklus II

\begin{tabular}{|l|c|c|}
\hline $\begin{array}{c}\text { Kegiat } \\
\text { an }\end{array}$ & $\begin{array}{c}\text { Nilai Rata } \\
\text { - Rata } \\
\text { Penyusun } \\
\text { an RPPH }\end{array}$ & $\begin{array}{c}\text { Peningkat } \\
\text { an }\end{array}$ \\
\hline $\begin{array}{l}\text { Kondisi } \\
\text { Awal }\end{array}$ & $59 \%$ & \\
\hline Siklus I & $67,83 \%$ & $8,83 \%$ \\
\hline $\begin{array}{l}\text { Siklus } \\
\text { II }\end{array}$ & $84,67 \%$ & $16,84 \%$ \\
\hline $\begin{array}{l}\text { Rata - Rata } \\
\text { peningkatan }\end{array}$ & $25,67 \%$ \\
\hline
\end{tabular}

Dari tabel diatas dapat dilihat nilai penyusunan RPPH guru pada kondisi awal sebelum dilakukan pelatihan dan bimbingan adalah $59 \%$, yang berada pada kategori kurang. Siklus I kemampuan guru dalam menyusun RPPH dengan melaksanakan latihan dan bimbingan diperoleh nilai rata - rata 67, $83 \%$ berada pada kategori cukup. Terjadi peningkatan sebesar $8,83 \%$ dari kondisi awal. Siklus II diperoleh nilai rata - rata kemampuan guru dalam meyusun
RPPh sebesar $84,67 \%$, mengalami peningkatan dari siklus I sebesar 16 , $84 \%$. Dilihat dari kondisi awal hingga kondisi akir siklus II mengalami peningkatan kemampuan guru dalam menyus RPPH sebesar $25,67 \%$. Hal ini membuktikan bahwa pelaksanaan latihan dan bimbingan dapat meningkatkan kemampuan guru dalam membuat RPPH. Hal ini sesuai dengan teori dari Mathis (2002), Pelatihan adalah proses dimana orang mencapai kemampuan tertentu untuk mencapai tujuan organisasi. Serta Menurut Prayitno \& Erman Amti (2004) bimbingan adalah proses pemberi bantuan yang dilakukan oleh orang yang ahli kepada seseorang atau beberapa orang individu,baik anak-anak remaja, maupun dewasa agar orang-orang yang dibimbing dapat mengembangkan kemampuan dirinya sendiri dan mandiri,dengan memanfaatkan kekuatan individu dan sarana yang ada dan dapat dikembangkan berdasarkan normanorma yang berlaku. Sehingga sesuai dengan teori - teori yang diambil dan kajian hasil - hasil penelitian yang relevan yang digunakan sebagai acuan dalam penelitian ini membuktikan bahwa 
pelatihan dan bimbingan dapat meningkatkan kemampuaan guru dalam menyusun Rencana Pelaksanaan Pembelajaran Harian (RPPH) bagi guru - guru TK/PAUD di gugus I kecamatan Wolomeze, Kapuaten Ngada TA 2018/2019. Sesuai dengan Indikator kinerja yaitu persentase jumlah skor perolehan kemampuan guru dalam penyusunan Rencana Pelaksanaan Pembelajaran Harian (RPPH) sebesar $25 \%$ maka penelitian ini dihentikan dan dinyatakan berhasil.

\section{PENUTUP}

Pelaksanaan Pelatihan dan Bimbingan dapat meningkatkan kemampuan guru dalam menyusun Rencana Pelaksanaan Pembelajaran bagi guru TK/PAUD gugus I Kecamatan Wolomeze, Kabupaten Ngada, hal ini di buktilkan dengan hasil penelitian diperoleh pada kondisi awal sebelum dilakukan pelatihan dan bimbingan adalah $59 \%$, yang berada pada kategori kurang. Siklus I kemampuan guru dalam menyusun RPPH dengan melaksanakan latihan dan bimbingan diperoleh nilai rata rata $67,83 \%$ berada pada kategori cukup. Terjadi peningkatan sebesar $8,83 \%$ dari kondisi awal. Siklus II diperoleh nilai rata - rata kemampuan guru dalam meyusun RPPH sebesar 84,67\%, berada pada kategori , mengalami peningkatan dari siklus I sebesar 16, $84 \%$. Dilihat dari kondisi awal hingga kondisi akir siklus II mengalami peningkatan kemampuan guru dalam menyus RPPH sebesar $25,67 \%$. Sehingga pelatihan dan bimbingan dapat meningkatkan kemampuaan guru dalam menyusun Rencana Pelaksanaan Pembelajaran Harian (RPPH) bagi guru - guru TK/PAUD di gugus I kecamatan Wolomeze, Kapuaten Ngada TA 2018/2019.

Sesuai dengan temuan pada penelitian diatas maka peneliti memberikan saran - saran sebagai berikut.

Penempatan atau perekrutan Guru TK/ PAUD hendaknya perlu dilihat kualifikasi dari guru sehingga tidak menyulitkan dalam pelaksanaaan pemmbelajaran di kelas

Apabila kekurangan SDM dalam hal ini adalah tenaga pendidik yang berkualifikasi sesuai dengan persyaratan, hendaknya guru - guru tersebut perlu di berikan dengan pelatihan dan bimbingan dalam bentuk Workhshop ataupun 
sejenisnya kususnya dalam penyusunan RPPH.

Motivasi yang sudah tertanam khususnya dalam penyusunan $\mathrm{RPPH}$ hendaknya terus dipertahankan dan ditingkatkan/ dikembangkan, oleh guru masingmasing

$\mathrm{RKH}$ yang disusun/dibuat hendaknya mengandung komponenkomponen RPPH secara lengkap dan baik karena RPPH merupakan acuan/pedoman dalam melaksanakan pembelajaran.

\section{DAFTAR PUSTAKA}

Amti, Erman dan Prayitno. 2004. Layanan bimbingan dan konseling kelompok. Padang: Jurusan Bimbingan dan Konseling Fakultas IImu
Pendidikan Universitas Negeri Padang.

Peraturan Pemerintah Nomor 19 Tahun 2005 Tentang Standar Nasional Pendidikan

Departemen Pendidikan Nasional, 2005. Undang-Undang Nomor 14 Tahun 2005, Tentang Guru dan Dosen, Jakarta: Depdiknas.

Depdiknas. (2014). Permendikbud No. 146 Tahun 2014. Jakarta: Depdiknas.

Mathis Robert, Jackson John. 2002. Manajemen Sumber Daya Manusia. Jakarta : Salemba empat

Mangkunegara, A.A. Anwar Prabu. 2005. Evaluasi Kinerja

Sudjana Nana dkk. 2011. Buku Kerja Pengawas Sekolah. Pusat Pengembangan Tenaga Kependidikan, Badan PSDM dan PMP. Jakarta: Kementerian Pendidikan dan Kebudayaan 